\title{
Employability Skills Needed by Higher Vocational Education Graduates to Be Successful in the Workplace
}

\author{
I Made Suarta \\ Bali State Polytechnic, Bali, Indonesia
}

\begin{abstract}
The current issues in workforce development are on high competence not only in technical skills, but also in non-technical skills. The term of non-technical skills is also called as employability skills. The research with topic analysis and development of employability skills of polytechnic students aims to: describe supervisors' perceptions of the importance of the employability skills needed in the workplace; describe supervisors' perceptions of the students' level of competence at performing the employability skills; and find the attributes of employability skills that are need to prioritize for development. Research sample has been selected by using a stratified random sampling from the supervisor of last year students when they are on the job training in industry. Total 146 supervisors participated in this research. The Employability Skills Questionnaire with a five-point Likert scale was used to assess perceptions level of importance of identified employability skills and students' level of competence. Data were analyzed by descriptive statistics, means and standard deviations, and priority development analysis. Three main groups of the employability skills with highest important level are: workplace health and safety, self-management, and team working. Students have a high level of competence in occupational health and safety, self-management and learning skills. There are three attributes of employability skills in high priority category for developed: knowing the benefits of computer application programs are needed in the work, taking the initiative in organizing activities, and participating in learning activities to gain new experience.
\end{abstract}

Key words: employability skills, higher vocational education, workforce development

\section{Introduction}

The new paradigm of global economy today is knowledge-based economy. Industry in the knowledge-based economy era requires workers who are called as knowledge workers (Hager \& Holland, 2006). In the era of knowledge-based economy, the workplace environment is changing rapidly. Characteristics of labor markets and employment qualifications are also changing rapidly (Tome, 2007). Workers at all levels are expected to solve problems, create ways to improve the methods which they used, and engage effectively with their coworkers.

As the knowledge economy realizes the full potential of new organizational models, a new pattern of work is emerging (Heerwagen, 2006). Cognitive workers are expected to be able to work functionally across many kinds of tasks and situations. As collaboration and collective activity become more prevalent, workers need

I Made Suarta, Dr., Lecturer, Accounting Department, Bali State Polytechnic.

Correspondence concerning this article should be addressed to I Made Suarta, Jln. Kampus Bukit Jimbaran, Badung, Bali, 80364 Indonesia. E-mail: i_md_suarta@yahoo.co.id. 
well-developed social skills including teamwork and collaboration, relationship development and networking abilities, and learning and growth relationships. Research findings (Cotton, 2001) addressed skills and traits employers' value in prospective entry-level employees and the importance of employability skills in contemporary workplaces. Employers expect entry-level employees to possess an array of basic, higher-order, and affective employability skills.

Employability skills have become a very important issue in recent years. Overttom (2000) defined employability skills as: “... transferable core skill groups that represent essential functional and enabling knowledge, skills, and attitudes required by the 21st century workplace. They are necessary for career success at all levels of employment and for all levels of education”. The Business Council of Australia and the Australian Chamber of Commerce and Industry defined employability skills as: “... skills required not only to gain employment, but also to progress within an enterprise to achieve one's potential and contribute successfully to enterprise strategic directions. Employability skills are also sometimes referred to as generic skills, capabilities or key competencies” (ABC/ACCI, 2002).

The employability of graduates has become an aim that governments around the world have, to varying extents, imposed on national higher education systems. Indonesian government expected to the vocational educations in preparation of human resource to overcome unemployment problems. Preparation of human resource is part of education and training. In consequence, education needs to develop in functionally interrelationship with various work types, each having different characteristics and problems. Polytechnic, as a part of Indonesian higher education system, carries out vocational education in several specific knowledge areas which are designed to help students become successful workers. Unlike the academic system, vocational education system is a system designed with the purpose of fulfilling the manpower demands of the industries by providing needed skills required at work places.

This study was designed to identify attributes of employability skills possessed by Bali States Polytechnic students. The main purpose of this study was to assess supervisors' perceptions of the importance of the employability skills needed by graduates to be successful in the workplace and assess the students' level of competence at performing those skills. The following specific objectives were used to guide the study: (1) describe supervisors' perceptions of the importance of the employability skills needed in the workplace; (2) describe supervisors' perceptions of the students' level of competence at performing the employability skills; and (3) find the employability skills attributes that need to prioritize for development.

\section{Theoretical Framework}

The interest of employers on improved employability skills of graduates has been well documented by many studies. Employability skills framework have been developed in many countries. Employability skills are also known by a number of terms overseas, such as core skills, key skills, essential skills, key competencies, generic skills, necessary skills, workplace know-how, critical enabling skills, transferable skills, key qualifications (SCANS, 1991; CBC, 2000; NCVER, 2003; Yorke, 2006). However, the study of employability skills framework in Indonesia is very limited.

The Conference Board of Canada recently has published Employability Skills 2000+ (CBC, 2000). The Employability Skills 2000+ consists of fundamental skills, personal management skills, and teamwork skills. 
Fundamental skills are the skills needed as a base for the further development. Personal management skills are the personal skills, attitudes, and behaviors that drive one's potential for growth. Teamwork skills are the skills and attributes needed to contribute productively. Employability Skills 2000+ consists of 56 set specific skills or attributes.

The Australian Chamber of Commerce and Industry, and the Business Council of Australia (BCA/ACCI, 2002) undertook a comprehensive study of the skills commonly required by both new and existing employees to work successfully in organizations. They derived a set of key skills, which they called employability skills. This is industry's preferred term for this set of generic skills. The report proposes an employability skills framework, which is made up of eight major skill groups and a variety of personal attributes. The eight skill groups are: communication, team work, problem-solving, initiative and enterprise, planning and organizing, self-management, learning, and technology skills (DEST, 2004). Personal attributes are terms used to describe a set of non-skill-based behaviors and attitudes that employers felt as important as the employability skills and other technical or job-specific skills. The personal attributes included loyalty, commitment, honesty and integrity, enthusiasm, reliability, personal presentation, commonsense, positive self-esteem, sense of humor, balanced attitude to work and home life, ability to deal with pressure, motivation, and adaptability.

The main framework of this study using eight major skill groups from BCA/ACCI. In this research, the author added one group of skills, namely workplace health and safety. Workplace safety is also the responsibility of individual employees (Kimbrell \& Vineyard, 2006). Workers must learn and follow safety regulations set, include the following: learn to perform a job safety; know how to operate, maintain, and troubleshoot tools and equipment safely; and report unsafe conditions or practices immediately.

\section{Research Method}

This research is ex-post facto research with survey method. Data were collected by self-administered questionnaires. The research population is the supervisor of students who are doing field work practices in industry. The number of student who is doing field work practices on academic year of 2009/2010 is 418 . The sample size is 146 chosen proportionally based on the number of students in each study program (see Table 1).

Table 1

Number of Sample Size Every Study Program

\begin{tabular}{|c|c|c|c|}
\hline Study program & Number of student & $\%$ of total & Number of sample \\
\hline Accounting & 77 & 18.42 & 27 \\
\hline Business administration & 65 & 15.55 & 23 \\
\hline Tour and travel & 38 & 9.09 & 13 \\
\hline Hotel and restaurant & 53 & 12.68 & 19 \\
\hline Civil engineering & 27 & 6.46 & 9 \\
\hline Electrical engineering & 52 & 12.44 & 18 \\
\hline Information management & 26 & 6.22 & 9 \\
\hline Mechanical engineering & 52 & 12.44 & 18 \\
\hline Refrigeration & 28 & 6.70 & 10 \\
\hline Total & 418 & 100 & 146 \\
\hline
\end{tabular}

The Employability Skills Questionnaire (ESQ) was used to collect the data, developed and adapted from 
document "Employability Skills for the Future" (BCA/ACCI, 2002) and some relevant literature (CBC, 2000; Kimbrell \& Vineyard, 2006). This instrument includes nine major skill groups, namely: communication skills consist of 10 attributes, teamwork skills of 6 attributes, problem-solving skills of 7 attributes, initiative and enterprise skills of 4 attributes, planning and organizing skills of 5 attributes, self-management skills of 9 attributes, learning skills of 7 attributes, technological skills of 7 attributes, and workplace health and safety skills of 4 attributes.

A five-point Likert scale with the following response choices is used to assess perceptions level of importance of identified employability skills: $1=$ not importance, $2=$ less importance, $3=$ uncertain, $4=$ importance, 5 = very importance. The response choices used to assess level of competence are: 1 = not competent, student cannot perform this skill; 2 = partly competent, student can perform parts of this skills, but requires considerable assistance and/or supervision; 3 = sufficiently competent, student can perform this skill, but requires some assistance and/or supervision; 4 = highly competent, student can perform this skill satisfactorily without assistance or supervision; and 5 = completely competence, student can perform this skills without supervision and with initiative and adaptability to problem situations.

Objectives one and two were analyzed by descriptive statistics, means, and standard deviations. The means then descending sorted to show the level of importance needed for the workplace and level of students' competence according to supervisor's perception. To address objective three, the data analyzed by priority development analysis model, with plotting the means level of competence and means level of importance employability skills attributes at Cartesian diagram. Horizontal axis ( $\bar{X}$ ) depicts level of competence, with $\overline{\bar{X}}$ point is average level of competence of all employability skills attributes. Vertical axis $(\bar{Y})$ depicts level of importance, with $\overline{\bar{Y}}$ point is average level of importance of all employability skills attributes. The intersection of $\overline{\bar{X}}$ and $\overline{\bar{Y}}$ will be forming four categories, namely: (1) high priority to be developed if $\bar{X}<\overline{\bar{X}}$ and $\bar{Y} \geq$ $\overline{\bar{Y}}$; (2) moderate priority if $\bar{X} \geq \overline{\bar{X}}$ and $\bar{Y} \geq \overline{\bar{Y}}$; (3) low priority if $\bar{X}<\overline{\bar{X}}$ and $\bar{Y}<\overline{\bar{Y}}$; and (4) can be neglected if $\bar{X} \geq \overline{\bar{X}}$ and $\bar{Y}<\overline{\bar{Y}}$.

\section{Results and Discussion}

\section{Demographic Data}

The total sample for the survey consists of 146 respondents, $86 \%$ males and $14 \%$ females. The average length of working as a supervisor is 10.1 years. The distribution is $16 \%$ as supervisor less than 1 year, $19 \%$ as supervisor 1-2 year, 15\% as supervisor 3-4 year, and 31\% as supervisor more than 5 year.

\section{Instrument Validity and Reliability}

The validity of the instrument was tested by using Pearson product moment correlation coefficient with $\alpha=$ $5 \%$. The employability skills framework consists of 60 specific skills or attributes, with coefficient Pearson product moment correlation varied from 0.408 (lowest) to 0.838 (highest), and the value of reliability (Cronbach’s Alpha) is 0.968.

\section{The Importance Level of Employability Skills Attributes}

Objective one describes supervisors' perceptions of the importance of the employability skills in the workplace. The importance level of major skill groups, sorted based on the mean scores was as follows: 
workplace health and safety skills $(M=4.450)$, self-management skills $(M=4.373)$, teamwork skills $(M=4.336)$, learning skills $(M=4.320)$, technology skills $(M=4.319)$, problem-solving skills $(M=4.275)$, planning and organizing skills ( $M=4.179)$, initiative and enterprise skills $(M=4.175)$, and communication skills $(M=4.016)$. The average of all skill groups is 4.258. Supervisors perceived the most important skills which consist of workplace health and safety skills, self-management skills, teamwork skills, learning skills, technology skills, and problem-solving skills.

The employability skills framework consists of 60 specific skills or attributes. The importance level of each attribute is sorted based on the average score (see Table 2). There are 10 employability skills attributes with the highest importance level: (1) on time in working; (2) implementing the workplace health and safety according to procedure; (3) responsible for the actions taken; (4) recognizing the problems in the work; (5) recognizing the function of working equipment; (6) understanding the workplace health and safety procedures; (7) following the workplace health and safety procedures; (8) showing a good working attitude; (9) selecting and using equipment properly; and (10) showing responsibility for tasks within the team. On the other hand, there are 10 employability skills attributes with lowest importance level are: (1) developing a communication style appropriate situations and conditions; (2) delivering information orally; (3) allocating resources in a variety of activities; (4) participating in the planning process and sustainable improvement; (5) implementing the development plan; (6) delivering information in written form; (7) listening the speech of others; (8) delivering information in the presentation form; (9) having oral and written communication in English; and (10) understanding and writing down the needs of others.

Table 2

Importance Level of the Employability Skill Attributes $(n=146)$

\begin{tabular}{llll}
\hline Rank & Employability skills attributes & Mean & SD \\
\hline 1 & On time in working & 4.6096 & 0.5678 \\
2 & Implementing the workplace health and safety & 4.5205 & 0.6014 \\
3 & Responsible for the actions taken & 4.5137 & 0.5661 \\
4 & Recognizing the problems in the work & 4.5000 & 0.5663 \\
5 & Recognizing the function of working equipment & 4.4863 & 0.6458 \\
6 & Understanding the workplace health and safety procedures & 4.4863 & 0.6564 \\
7 & Following the workplace health and safety procedures & 4.4794 & 0.5410 \\
8 & Showing a good working attitude & 4.4521 & 0.5998 \\
9 & Selecting and using equipment properly & 4.4521 & 0.6112 \\
10 & Showing responsibility for tasks within the team & 4.4384 & 0.5249 \\
11 & Consistently implementing the work plan & 4.4041 & 0.6055 \\
12 & Opening to accept new knowledge and skills & 4.4041 & 0.5940 \\
13 & Maintaining work equipment & 4.3973 & 0.6377 \\
14 & Speaking directly and clearly & 4.3836 & 0.5903 \\
15 & Supporting decision making by objective and sophisticated data & 4.3836 & 0.6671 \\
16 & Having confidence in the ability to complete the work & 4.3767 & 0.5889 \\
17 & Conducting self-evaluation and improving performance & 4.3699 & 0.5990 \\
18 & Improving the work based on previous experience & 4.3699 & 0.5874 \\
19 & Adaptation to new situations & 4.3699 & 0.5874 \\
21 & Managing time and priorities for actions & 4.3630 & 0.6311
\end{tabular}




\begin{tabular}{|c|c|c|c|}
\hline Rank & Employability skills attributes & Mean & SD \\
\hline 22 & Sharing knowledge, opinions and ideas in working & 4.3493 & 0.6169 \\
\hline 23 & Encouraging other members to actively participate in team & 4.3356 & 0.6568 \\
\hline 24 & Innovating to improve productivity and efficiency in the work & 4.3356 & 0.5905 \\
\hline 25 & Understanding the dangers of working & 4.3151 & 0.6075 \\
\hline 26 & Utilizing the prior knowledge and skills to the current task & 4.3082 & 0.6277 \\
\hline 27 & Aligning individual goals and team goals & 4.3014 & 0.6682 \\
\hline 28 & Sharing information with others & 4.2945 & 0.6451 \\
\hline 29 & Exploring the relevant information for decision making & 4.2945 & 0.6661 \\
\hline 30 & Understanding the speech of others & 4.2808 & 0.7678 \\
\hline 31 & Be calm in dealing with stressful situations & 4.2808 & 0.6617 \\
\hline 32 & Using the computer to complete the work & 4.2808 & 0.6822 \\
\hline 33 & Exploring the alternative to overcome the problems in the work & 4.2671 & 0.6356 \\
\hline 34 & Formulating a priority in solving the problems of work & 4.2603 & 0.6954 \\
\hline 35 & Taking the initiative in organizing activities & 4.2466 & 0.6166 \\
\hline 36 & Having the ability to make work plan systematically & 4.2466 & 0.6493 \\
\hline 37 & Knowing the benefits of computer application programs & 4.2397 & 0.6675 \\
\hline 38 & Appreciating the ability, opinions or contributions of others & 4.2329 & 0.6952 \\
\hline 39 & Participating in learning activities to get new experience & 4.2260 & 0.6620 \\
\hline 40 & Accepting and understanding new information quickly & 4.2260 & 0.5480 \\
\hline 41 & Developing long-term vision & 4.2123 & 0.7067 \\
\hline 42 & Creating a clear project goals and can be implemented & 4.2123 & 0.6969 \\
\hline 43 & Maintaining hardware/software to function properly & 4.2123 & 0.7164 \\
\hline 44 & Developing business strategies & 4.1986 & 0.6499 \\
\hline 45 & Evaluating the past decisions for consistency & 4.1918 & 0.6249 \\
\hline 46 & Identifying business opportunities & 4.1644 & 0.5875 \\
\hline 47 & Suggesting improvements and replacement of equipment & 4.1644 & 0.6542 \\
\hline 48 & Initiating creative and innovative ideas & 4.1575 & 0.5594 \\
\hline 49 & Translating ideas into action & 4.1438 & 0.7046 \\
\hline 50 & Asking for help if necessary & 4.1027 & 0.7495 \\
\hline 51 & Developing a communication style & 4.0959 & 0.7079 \\
\hline 52 & Delivering information orally & 4.0753 & 0.6857 \\
\hline 53 & Allocating resources in a variety of activities & 4.0411 & 0.7690 \\
\hline 54 & Participating in the planning and sustainable improvement & 4.0342 & 0.7373 \\
\hline 55 & Implementing the development plan & 4.0274 & 0.6741 \\
\hline 56 & Delivering information in written form & 3.9863 & 0.8220 \\
\hline 57 & Listening the speech of others & 3.9178 & 1.2177 \\
\hline 58 & Delivering information in the presentation form & 3.8288 & 0.8498 \\
\hline 59 & Having oral and written communication in English & 3.7468 & 0.9233 \\
\hline 60 & Understanding and writing down the needs of others & 3.5548 & 1.0308 \\
\hline \multicolumn{2}{|c|}{ Mean all item } & 4.2584 & \\
\hline
\end{tabular}

\section{Students' Level Competence of the Employability Skills Attributes}

Objective two describes supervisors' perceptions of the students' level of competence at performing the employability skills. Students' competence level of major employability skill groups, sorted based on the mean scores was as follows: workplace health and safety skills $(M=4.039)$, self-management skills $(M=3.961)$, learning skills $(M=3.921)$, technology skills $(M=3.919)$, teamwork skills $(M=3.886)$, problem-solving skills $(M=3.818)$, planning and organizing skills $(M=3.790)$, initiative and enterprise skills $(M=3.684)$, and 
communication skills ( $M=3.613)$. The average of all skill groups is 3.837. Supervisors perceive graduates to be competent at workplace health and safety skills, self-management skills, learning skills, technology skills, and teamwork skills.

The 60 employability skills attributes were ranked in order of the students' level of competence (see Table 3). There are 10 employability skills attributes with highest competence level: (1) on time in working; (2) showing a good working attitude; (3) understanding the workplace health and safety procedures; (4) following the workplace health and safety procedures; (5) recognizing the function of working equipment; (6) utilizing the previous knowledge and skills to performing the current duties; (7) improving the working based on previous experience; (8) being responsible for the actions taken; (9) implementing the workplace health and safety according to procedure; and (10) showing responsibility for tasks within the team. On the other hand, there are 10 employability skills attributes with lowest competence: (1) initiating creative and innovative ideas; (2) participating in the planning process and sustainable improvement; (3) identifying business opportunities; (4) delivering information in written form; (5) developing a communication style in appropriate situations and conditions; (6) listening the speech of others; (7) implementing the development plan; (8) delivering information in the presentation form; (9) having oral and written communication in English; and (10) understanding and writing down the needs of others.

Table 3

Students' Level Competence of the Employability Skill Attributes $(n=146)$

\begin{tabular}{|c|c|c|c|}
\hline Rank & Employability skills attributes & Mean & SD \\
\hline 1 & On time in working & 4.2534 & 0.7126 \\
\hline 2 & Showing a good working attitude & 4.1027 & 0.7677 \\
\hline 3 & Understanding the workplace health and safety procedures & 4.1027 & 0.7766 \\
\hline 4 & Following the workplace health and safety procedures & 4.0959 & 0.8165 \\
\hline 5 & Recognizing the function of working equipment & 4.0822 & 0.7288 \\
\hline 6 & Utilizing the prior knowledge and skills to the current task & 4.0753 & 0.7436 \\
\hline 7 & Improving the work based on previous experience & 4.0685 & 0.7936 \\
\hline 8 & Having responsible for the actions taken & 4.0616 & 0.6239 \\
\hline 9 & Implementing the workplace health and safety & 4.0616 & 0.7898 \\
\hline 10 & Showing responsibility for tasks within the team & 4.0479 & 0.7731 \\
\hline 11 & Selecting and using equipment properly & 4.0479 & 0.7641 \\
\hline 12 & Recognizing the problems in the work & 4.0412 & 0.7600 \\
\hline 13 & Maintaining work equipment & 4.0137 & 0.7143 \\
\hline 14 & Using the computer to complete the work & 3.9932 & 0.7381 \\
\hline 15 & Consistently implement the work plan & 3.9726 & 0.8465 \\
\hline 16 & Conducting self-evaluation and improve performance & 3.9726 & 0.7874 \\
\hline 17 & Supporting decision making by objective and sophisticated data & 3.9658 & 0.8583 \\
\hline 18 & Sharing knowledge, opinions and ideas in working & 3.9521 & 0.7366 \\
\hline 19 & Having confidence in the ability to complete the work & 3.9521 & 0.7820 \\
\hline 20 & Speaking directly and clearly & 3.9452 & 0.7314 \\
\hline 21 & Openning to accept new knowledge and skills & 3.9384 & 0.7165 \\
\hline 22 & Supporting the decisions taken by the team & 3.9315 & 0.7302 \\
\hline 23 & Managing time and priorities for actions & 3.9315 & 0.8108 \\
\hline 24 & Adaptation to new situations & 3.9315 & 0.7396 \\
\hline 25 & Sharing information with others & 3.9109 & 0.7783 \\
\hline
\end{tabular}




\begin{tabular}{|c|c|c|c|}
\hline Rank & Employability skills attributes & Mean & SD \\
\hline 26 & Understanding the dangers of working & 3.8973 & 0.8282 \\
\hline 27 & Having innovative to improve productivity and efficiency in the work & 3.8767 & 0.7781 \\
\hline 28 & Knowing the benefits of computer application programs & 3.8699 & 0.8571 \\
\hline 29 & Taking the initiative in organizing activities & 3.8562 & 0.7427 \\
\hline 30 & Participating in learning activities to get new experience & 3.8562 & 0.7877 \\
\hline 31 & Exploring the alternative to overcome the problems in the work & 3.8493 & 0.7821 \\
\hline 32 & Be calm in dealing with stressful situations & 3.8288 & 0.8579 \\
\hline 33 & Appreciating the ability, opinions or contributions of others & 3.8219 & 0.7762 \\
\hline 34 & Encouraging other members to actively participate in team & 3.8082 & 0.8413 \\
\hline 35 & Formulating a priority in solving the problems of work & 3.8082 & 0.8575 \\
\hline 36 & Creating a clear project goals and can be implemented & 3.8014 & 0.9219 \\
\hline 37 & Exploring the relevant information for decision making & 3.7945 & 0.8045 \\
\hline 38 & Having ability to make work plan systematically & 3.7671 & 0.8634 \\
\hline 39 & Suggesting improvements and replacement of equipment & 3.7671 & 0.7882 \\
\hline 40 & Understanding the speech of others & 3.7534 & 0.8595 \\
\hline 41 & Aligning individual goals and team goals & 3.7534 & 0.7662 \\
\hline 42 & Asking for help if necessary & 3.7397 & 0.7706 \\
\hline 43 & Translating ideas into action & 3.7329 & 0.8493 \\
\hline 44 & Allocating resources in a variety of activities & 3.7192 & 0.8529 \\
\hline 45 & Evaluating the past decisions for consistency & 3.7123 & 0.9094 \\
\hline 46 & Developing long-term vision & 3.7123 & 0.9094 \\
\hline 47 & Developing business strategies & 3.6986 & 0.9200 \\
\hline 48 & Accepting and understanding new information quickly & 3.6986 & 0.7369 \\
\hline 49 & Delivering information orally & 3.6575 & 0.7468 \\
\hline 50 & Maintaining hardware/software to function properly & 3.6575 & 0.9130 \\
\hline 51 & Initiating creative and innovative ideas & 3.6438 & 0.7496 \\
\hline 52 & Participating in the planning and sustainable improvement & 3.6438 & 0.8366 \\
\hline 53 & Identifying business opportunities & 3.6301 & 0.7703 \\
\hline 54 & Delivering information in written form & 3.6096 & 0.8660 \\
\hline 55 & Developing a communication style & 3.5890 & 0.8360 \\
\hline 56 & Listening the speech of others & 3.5548 & 1.0173 \\
\hline 57 & Implementing the development plan & 3.5548 & 0.8139 \\
\hline 58 & Delivering information in the presentation form & 3.4795 & 0.9485 \\
\hline 59 & Having oral and written communication in English & 3.3288 & 1.0178 \\
\hline 60 & Understanding and writing down the needs of others & 3.3014 & 1.0128 \\
\hline \multicolumn{2}{|c|}{ Mean all item } & 3.8371 & \\
\hline
\end{tabular}

\section{Priority Development of Employability Skill Attributes}

Objective three finds the employability skills attributes that are need to prioritize for development. There are three attributes included in category I, 28 attributes in category II, 23 attributes in category III, and 6 attributes in category IV. Based on attributes that include in categories I and II (see Table 4), there are 31 attributes of employability skills that need to be prioritized to develop the competencies. The research results are in line with Robinson's research (2006, p. 104). The attributes of employability skills such as on time in working, being responsible for the actions taken, adaptation to new situations, exploring the alternative to overcome the problems in the work are part of the 31 attributes which were identified to get priority to develop. There are three attributes in the category of high priority for developement (1) knowing the benefits of computer application 
programs which are needed in the work; (2) taking the initiative in organizing activities; and (3) participating in learning activities to get new experience.

Table 4

The Employability Skills Attributes That Need to Prioritized for Development ( $n=146)$

\begin{tabular}{|c|c|c|c|}
\hline Category & Employability skills attributes & Mean of competence & Mean of importance \\
\hline \multirow[t]{3}{*}{$\overline{\mathrm{I}}$} & Knowing the benefits of computer application programs & 3.8699 & 4.2397 \\
\hline & Taking the initiative in organizing activities & 3.8562 & 4.2466 \\
\hline & Participating in learning activities to get new experience & 3.8562 & 4.2260 \\
\hline \multirow[t]{28}{*}{ II } & On time in working & 4.2534 & 4.6096 \\
\hline & Showing a good working attitude & 4.1027 & 4.4521 \\
\hline & Understanding the workplace health and safety procedures & 4.1027 & 4.4863 \\
\hline & Following the workplace health and safety procedures & 4.0959 & 4.4795 \\
\hline & Recognizing the function of working equipment & 4.0822 & 4.4863 \\
\hline & Utilizing the prior knowledge and skills to the current task & 4.0753 & 4.3082 \\
\hline & Improving the work based on previous experience & 4.0685 & 4.3699 \\
\hline & Having responsible for the actions taken & 4.0616 & 4.5137 \\
\hline & Implementing the workplace health and safety & 4.0616 & 4.5205 \\
\hline & Showing responsibility for tasks within the team & 4.0479 & 4.4384 \\
\hline & Selecting and using equipment properly & 4.0479 & 4.4521 \\
\hline & Recognizing the problems in the work & 4.0412 & 4.500 \\
\hline & Maintaining work equipment & 4.0137 & 4.3973 \\
\hline & Using the computer to complete the work & 3.9932 & 4.2808 \\
\hline & Consistently implementing the work plan & 3.9726 & 4.4041 \\
\hline & Conducting self-evaluation and improving performance & 3.9726 & 4.3699 \\
\hline & Supporting decision making by objective and sophisticated data & 3.9658 & 4.3836 \\
\hline & Sharing knowledge, opinions and ideas in working & 3.9521 & 4.3493 \\
\hline & Having confidence to complete the work & 3.9521 & 4.3767 \\
\hline & Speaking directly and clearly & 3.9452 & 4.3836 \\
\hline & Openning to accept new knowledge and skills & 3.9384 & 4.4041 \\
\hline & Supporting the decisions taken by the team & 3.9315 & 4.3562 \\
\hline & Managing time and priorities for actions & 3.9315 & 4.3630 \\
\hline & Adaptation to new situations & 3.9315 & 4.3699 \\
\hline & Sharing information with others & 3.9109 & 4.2945 \\
\hline & Understanding the dangers of working & 3.8973 & 4.3151 \\
\hline & Having innovative to improve productivity and efficiency & 3.8767 & 4.3356 \\
\hline & Exploring the alternative to overcome the problems in the work & 3.8493 & 4.2671 \\
\hline
\end{tabular}

If we observed furthermore, there are two attributes are representation of communication skills group, four attributes are representation of team work skills group, two attributes are representation of problem-solving skills group, two attributes are representation of planning and organising skills group, six attributes are representation of self-management skills group, six attributes are representation of learning skills group, five attributes are representation of technology skills groups, and four attributes are representation of workplace health and safety skills group.

Based on these results, we concluded technology skills, planning and organising skills, and learning skills to be the skill area in greatest need of curricular attention. It indicates by three employability skills attributes which are: (1) knowing the benefits of computer application programs which are needed in the work; (2) taking the 
initiative in organizing activities; and (3) participating in learning activities to get new experience which have a high priority to develop. However, initiative and enterprise skills groups do not get priority in development.

\section{Conclusions and Recommendations}

Workplace health and safety skills, self-management skills, and team work skills are three groups of the employability skill groups with the highest important level. The students have highest competence in workplace health and safety, self-management, and learning skills. There are 31 employability skills attributes that need to be developed and improved the competencies, representation of communication skills, team work skills, problem-solving skills, planning and organising skills, self-management skills, learning skills, technology skills, workplace health and safety. The initiative and enterprise skills group do not have attributes to get priority to be developed. Employability skills attributes that a high need for development are: knowing the benefits of computer application programs which are needed in the work; taking the initiative in organizing activities; and participating in learning activities to get new experience.

Bali State Polytechnic faculty members and administrators are always seeking ways to better prepare students for the workplace. Because technology skills, planning and organizing skills, and learning skills have a high need for development, the author recommend that there should have identified ways to modify current curriculum by entering three main aspects of employability skills.

\section{References}

BCA/ACCI. (2002). Employability skills for the future. A Report by the Australian Chamber of Commerce and Industry (ACCI) and the Business Council of Australia (BCA) for the Department of Education, Science and Training, Canberra.

Conference Board of Canada (CBC). (2000). Employability skills 2000+. Retrieved July 28, 2008, from http://www.conferenceboard.ca/education/learning-tools/pdfs/ esp2000.pdf

Cotton, K. (2001). Developing employability skills. School Improvement Research Series, NWREL. Retrieved April 1, 2008, from http://www.nwrel.org/scpd/sirs/8/c015.html

Department of Education, Science and Training (DEST). (2004). Employability skills. Final Report: Development of a Strategy to Support the Universal Recognition and Recording of Employability Skills. Retrieved July 11, 2008, from http://www.dest.gov.au/NR/rdonlyres/9F3D1FC5-45CD-468E-88D6-97B9ADE/4055/

UniversalRecognitionofEmployabilitySkillsProjectFi.pdf

Hager, P., \& Holland, S. (2006). Graduate attributes, learning, and employability. The Netherlands: Springer.

Heerwagen, J. (2006). The changing nature of organizations, work, workplace. Retrieved July 19, 2008, from http://www.wbdg.org/design/chngorgwork.php

Kimbrell, G., \& Vineyard, B. S. (2006). Succeeding in the world of work. New York: McGraw-Hill Companies.

NCVER. (2003). Defining generic skills: At a glance. Adelaide, Australia: National Centre for Vocational Education Research (NCVER).

Overtoom, C. (2000). Employability skills: An update. ERIC Digest No. 220. Columbus, Ohio: ERIC Clearinghouse on Adult, Career, and Vocational Education. Retrieved July 12, 2008, from http://www.ericdigests.org/2001-2/skills.htm

Robinson, J. S. (2006). Graduates' and employers' perceptions of entry-level employability skills needed by agricultural, food and natural resources graduates (Doctoral Dissertation (unpublished), Columbia: University of Missouri).

Secretary's Commission on Achieving Necessary Skills (SCANS). (1991). What works requires of schools: A SCANS report for America 2000. Washington, D. C.: Department of Labor.

Tome, E. (2007). Employability, skills and training in Portugal (1988-2000): Evidence from official data. Journal of European Industrial Training, 31(5), 336-357.

Yorke, M. (2006). Employability in higher education: What it is-What it is not. York, United Kingdom: The Higher Education Academy. 